\title{
Tendance et fait, logique et histoire
}

\section{Robert Cresswell}

\section{OpenEdition}

\section{Journals}

Édition électronique

URL : https://journals.openedition.org/tc/605

DOI : $10.4000 /$ tc. 605

ISSN : 1952-420X

\section{Éditeur}

Éditions de l'EHESS

\section{Édition imprimée}

Date de publication : 1 septembre 1994

ISSN : 0248-6016

\section{Référence électronique}

Robert Cresswell, «Tendance et fait, logique et histoire », Techniques \& Culture [En ligne], 21 | 1994, mis en ligne le 30 décembre 2005, consulté le 29 septembre 2022. URL : http://journals.openedition.org/ tc/605; DOI : https://doi.org/10.4000/tc.605

Ce document a été généré automatiquement le 29 septembre 2022

Tous droits réservés 


\section{Tendance et fait, logique et histoire}

Robert Cresswell 